The Politics of Being a Woman 


\section{The Politics of Being a Woman}

Feminism, Media and 21st Century Popular Culture

Edited by

Heather Savigny

Bournemouth University, UK

and

Helen Warner

University of East Anglia, UK

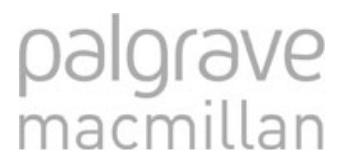




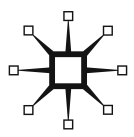

Selection, introduction, conclusion and editorial matter (c) Heather Savigny and Helen Warner 2015

Foreword () Liesbet Van Zoonen 2015

Afterword (c) Kat Banyard 2015

Remaining chapters () Individual authors 2015

Softcover reprint of the hardcover 1st edition 2015 978-137-38465-2

All rights reserved. No reproduction, copy or transmission of this publication may be made without written permission.

No portion of this publication may be reproduced, copied or transmitted save with written permission or in accordance with the provisions of the Copyright, Designs and Patents Act 1988, or under the terms of any licence permitting limited copying issued by the Copyright Licensing Agency, Saffron House, 6-10 Kirby Street, London, EC1N 8TS.

Any person who does any unauthorized act in relation to this publication may be liable to criminal prosecution and civil claims for damages.

The authors have asserted their rights to be identified as the authors of this work in accordance with the Copyright, Designs and

Patents Act 1988.

First published 2015 by

PALGRAVE MACMILLAN

Palgrave Macmillan in the UK is an imprint of Macmillan Publishers

Limited, registered in England, company number 785998, of Houndsmills, Basingstoke, Hampshire, RG21 6XS.

Palgrave Macmillan in the US is a division of St Martin's Press LLC, 175 Fifth Avenue, New York, NY 10010.

Palgrave is the global academic imprint of the above companies and has companies and representatives throughout the world.

Palgrave ${ }^{\circledR}$ and Macmillan ${ }^{\circledR}$ are registered trademarks in the United States, the United Kingdom, Europe and other countries.

ISBN 978-1-349-48098-2

ISBN 978-1-137-38466-9 (eBook)

DOI $10.1057 / 9781137384669$

This book is printed on paper suitable for recycling and made from fully managed and sustained forest sources. Logging, pulping and manufacturing.

processes are expected to conform to the environmental regulations of the country of origin.

A catalogue record for this book is available from the British Library.

A catalog record for this book is available from the Library of Congress.

Typeset by MPS Limited, Chennai, India. 
To Sam, Simon \& Lewis 


\section{Contents}

List of Figures and Tables ix

Foreword by Liesbet Van Zoonen $\quad \mathrm{x}$

Acknowledgements $\quad \mathrm{xV}$

$\begin{array}{ll}\text { Notes on Contributors } & \text { xvi }\end{array}$

1 Introduction: The Politics of Being a Woman 1

Heather Savigny and Helen Warner

Part I The Politics of Politics in Popular Culture

2 Seen and Not Heard: The Popular Appeal of Postfeminist Political Celebrity 27 Emily Harmer

3 'Honour Is Everything for Muslims'? Vendetta Song, Filmic Representation, Religious Identity and Gender Politics in Turkey Eylem Atakav

Part II The Politics of Politics: Role Models

4 'I'm a Free Bitch Baby', a 'Material Girl': Interrogating Audience Interpretations of the Postfeminist Performances of Lady Gaga and Madonna Oliver Brooks

5 'A Place for Talking about Female Stars': Exploring Versatility, Femininity and 'Fantasy' in Mother-Daughter talk on Film Stars

Sarah Ralph

6 'Where Do You Go after Bridesmaids?': The Politics of Being a Woman in Hollywood Helen Warner and Heather Savigny 
Part III The Politics of Being a Woman in 'Real Life'

7 'I'd Rather Be Peggy than Betty': Female Audience Responses to Mad Men

Katixa Agirre

8 Girls and Cultural Consumption: 'Typical Girls', 'Fangirls' and the Value of Femininity

Victoria Cann

9 Conclusion: Politics beyond Media and Popular Culture - I am a Feminist Because... A Manifesta Heather Savigny and Helen Warner

Afterword by Kat Banyard

Index 


\section{List of Figures and Tables}

Figures

9.1-9.21 'I'm a feminist because' signs

\section{Tables}

2.1 Percentage of items with photos across newspapers 2010

2.2 Reference to appearance across newspapers 2010

2.3 Percentage of items about each group of women 2010 


\section{Foreword}

A book like the one you are about to read is always both an inspiration and a frustration. An inspiration because it shows how feminist media studies, after some 40 years of existence, is a vibrant research field that never ceases to produce solid, interesting and engaged academic work. A frustration because much of that same work demonstrates a worrying lack of change in its objects of study, the media. Already in 1978, American scholars Gaye Tuchman, Arlene Kaplan Daniels and James Benét collected a number of studies about women and media under the title Hearth \& Home: Images of Women in the Mass Media. They said they were interested in 'the progress we are making toward the full social equality of women in this society' and that 'most people believe the media have an influence' (p. v). They acknowledged that the experts are undecided about how big this influence is and how it works exactly, and they introduced their book as an encouragement to others to study 'the interaction between the media and public opinion in the press for equality between the sexes (p. vi). The chapters in the book covered analyses of women's images in television, women's magazines and newspapers, and studies of the effects of sexist media on children. At the end, a bibliography was included which showed how the study of women and media began in concert with the emergence of the second wave women's movement. Many of the early 1970s studies were initiated by the National Organisation of Women.

Looking back at the 1978 collection we see, predictably, quite a lot of change: we speak, nowadays, of gender rather than of women; we prefer to speak of gender as 'performance' and don't see it simply as the end product of early age sex role socialisation; we acknowledge, through the concept of intersectionality, that gender is not the only dimension of identity that produces exclusion and oppression and have become sensitive to sexuality and ethnicity, and - to a lesser extent - to disability and religion (attention to class remains still very much a British thing). Words like 'articulation' or 'bricolage' point at the fact that we no longer assume simple and direct effects of sexist media on women's and girls' lives but recognise, instead, 
that women actively use and interpret their media, making them relevant to their own beliefs and everyday practices. 'Text' instead of 'content' is the word that clarifies that we read our media and are not simply overwhelmed by them. Our theories and concepts, in sum, have changed tremendously. The media we study have changed too; we have witnessed an explosion of new digital and mobile forms all captured under the heading of 'the internet', while no old media have disappeared (although they have changed a lot in themselves). We have seen a new entertainment industry emerge that has become bigger than Hollywood and that produces games that vary from high quality visual and narrative challenges to simple swap and play. And in contrast to the multi-million dollar media industries, we have seen an upsurge of personal media production, through social media status updates, selfies, blog posts, life logs or webcam diaries. No wonder that many an author claims nowadays that we live in or through media (Deuze, 2012) and that we can no longer distinguish them as separate factors in our lives; like a fish cannot recognise the water it lives in, we can no longer distinguish the media from ourselves (as McLuhan claimed already in the early sixties of the last century).

Such a metaphor seems to move the field of feminist media studies to a much wider focus on the way our overall symbolic environment is constructed, regardless of the particular media through which this takes place. This move is reflected in the approach many of the authors contributing to the volume at hand take: they focus on the way politicians' wives, Lady Gaga, Madonna or other female celebrities are represented in an array of media, and demonstrate how these representations together construct intertextual cultural personas. It is such a celebrity persona rather than specific media content that carries and expresses the discourses of femininity through which we live; traditional, as the chapters show, when it comes to politicians' wives and the majority of female pop, television and movie stars, more contested in the case of Madonna and Lady Gaga.

The celebrity culture of which Madonna and Lady Gaga are only a few of the leading icons, has brought the discussion of positive role models for women and girls back on the feminist and wider public agenda. In 1978, Gaye Tuchman introduced, on the basis of the then existing research, the notion of 'symbolic annihilation' of women and girls in the media, meaning that media either make women invisible, or portray them as incompetent. In 21st century celebrity 
culture, invisibility is no longer an issue, and the portrayal of incompetence has changed in the sense that women's competence with respect to body, beauty and hyper-heterosexuality is now the media discourse in which we have to live our lives. Abundant are the examples of young women whom we could admire for the way they use their bodies to build a position of individual power, with Beyoncé and Miley Cyrus possibly topping the list.

Paradoxically, that mainstream culture contains its own criticism; governments and professional organisations have produced reports and policies against the sexualisation of culture, and the cultural industries themselves eagerly produce stories and images that emphasise the artificial and constructed nature of current ideals of sexy femininity. The schizophrenic case of Dove, a product line for body care, is typical: Dove promotes its products using models of diverse age, ethnicity and size. Under the slogan of 'real beauty' it has produced videos that reveal the tricks of photo-shopping in advertising, and criticise the effects this has on young girls. It also runs a project for girls' 'self-esteem'. Yet, its parent company Unilever also produces the deeply sexist campaigns for its men's deodorant Axe, and the deeply racist campaign for its skin-whitening cream Fair and Lovely. The ultimate proof of the opportunistic logic of capitalism is that Unilever acquired both the Slim-Fast company and Ben and Jerry's ice-cream on the same day. ${ }^{1}$ There are many examples like this: a month after Australian movie star Nicole Kidman became ambassador for the UN Development Fund for Women (UNIFEM) and criticised Hollywood's sexualised portrayal of women in her inaugural speech, she appeared on the cover of Gentleman's Quarterly dressed in black lingerie only. ${ }^{2}$

There is quite a bit of attention to such paradoxes in this volume; not only in the analysis of actual texts (for instance the criticism implicit in Mad Men's celebration of 1950s masculinity), but especially in the analysis of audience responses to celebrities and other instances of popular culture. It seems that many, probably most, of us are aware of the nasty tricks that pop culture plays us; girls as young as twelve appear to understand why Britney Spears and Miley Cyrus all of a sudden turn to the performance of sexy (Duits and Van Romondt Vis, 2009), and appear to be highly critical of this. Time and again, and in the chapters here too, it turns out that mothers, the role-models at arm's length, are crucial in the negotiation of such 
images. To return to the fish and the water metaphor, we recognise our water because mothers teach us how and where to swim in the vast seas of gender discourse.

But who helps us to get out of the water altogether? Dove and its corporate companions may tell us that we need to acknowledge 'real beauty', but that is still a discourse about beauty, and not about strength, independence, creativity, intelligence, compassion, or whatever else that is not about the appearance of our bodies. In Gaye Tuchman's times there was the sisterhood (how helpful family metaphors are) of the women's movement to offer such alternatives, but where are the feminists these days and what alternatives do they offer? A group like Femen, originating in the Ukraine but now operating in many other countries as well, also keep within the woman = body = beauty framework, be it that they use their body and their bare breasts as means of aggressive protest thus disabling and challenging the traditional male gaze. But they keep us in the water, instead of getting us on land where we belong (after all, we are not fish).

What is feminism and how to be a feminist, are questions that have come back through the actions of Femen, but also through a range of other initiatives like the Everyday Sexism project which uses social media to 'record stories of sexism faced on a daily basis, by ordinary women, in ordinary places. To show that sexism exists in abundance in the UK workplace and that it is very far from being a problem we no longer need to discuss. ${ }^{3}$ If we would dig deeper into the wide and diverse range of current social media, we would find a wealth of feminist activity that belies the mainstream notion that feminism is dead. Some even claim social media is offering the means for a fourth wave of feminism (e.g. Munro, 2013; Schuster, 2013). We would also find a vehement backlash on those same social media by trolls, bullies and other griefers who will try to silence every woman, and especially those calling themselves feminist, as - among others - media and game critic Anita Sarkeesian of Feminist Frequency can testify. ${ }^{4}$ In the face of all such hate, against feminists, against women with brains, but effortlessly against all other women as well, to say one is not a feminist (but...) is the act of a coward. It is a brave and original twitch of this volume, therefore, that the editors asked all authors to claim their kind of feminism and begin their chapter with finishing the sentence "I am a feminist because ..." and "I am 
a feminist if ...". There is no hiding behind overly complex theoretical jargon here, but a straightforward imposition of the politics of feminist media research. And rightly so. I am a feminist because only then I can be many women at the same time.

\section{Liesbet Van Zoonen \\ Professor of Communication and Media Studies Loughborough University, UK}

\section{References}

Deuze, M. (2012). Media Life. (Cambridge: Polity Press).

Duits, L., \& van Romondt Vis, P. (2009). 'Girls Make Sense: Girls, Celebrities and Identities' European Journal of Cultural Studies, 12(1), 41-58.

Krijnen, T., Alvares, C. \& Van Bauwel, S. (2011, eds). Gendered Transformations: Theory and Practices on Gender and Media. ECREA Series. (Bristol, UK: Intellect).

Munro, E. (2013). 'Feminism: A Fourth Wave?' Political Insight, 4(2), 22-25.

Schuster, J. (2013). 'Invisible Feminists? Social Media and Young Women's Political Participation' Political Science, 65(1), 8-24. 


\section{Acknowledgements}

We would like to thank all of those who have engaged with this project and made it so much fun to be involved with. To all our feminists at the back of the book and to all who have taken the time to engage with the intellectual content in what follows. In particular we would like to thank the reviewers, Jenny Alexander, Jenny Cooper, Simon Gerrard, Rowan Landis, Sam Sleight, Lewis Swift, Lynne Warner, Dan Weissman, Rowan Whiteside, Shelley Thompson, Amber Burton, Nathan Farrell, Anna Feigenbaum, Dan Jackson, David McQueen, Barry Richards and Pawel Surowiec, all of the 'brown bag' friends and colleagues in the Media School at Bournemouth University, the University of East Anglia Feminist Society and ResNet. A special thanks goes to Liesbet Van Zoonen and Kat Banyard for taking time out of their busy schedules to support us. We would like to thank the anonymous reviewers for their insightful comments. And to Felicity and Chris, Geetha and the copy editors and all at Palgrave Macmillan - thank you for being such a pleasure to work with. 


\section{Notes on Contributors}

Katixa Agirre is a lecturer in Audiovisual Communication at the University of the Basque Country (Spain). She completed her Phd in 2010 with a dissertation that looked at the filmic representations of the Lolita myth in Hollywood cinema. Thanks to a grant from the Basque Government for the period 2011-2013 she was a postdoctoral researcher at Queen Mary, University of London and the School of Film, Television and Media Studies, University of East Anglia, where she got started in the fascinating world of audience studies.

Eylem Atakav is Senior Lecturer in Film and Television Studies at the University of East Anglia where she teaches courses on women and film; women, Islam and media; and Middle Eastern media. She is the author of Women and Turkish Cinema: Gender Politics, Cultural Identity and Representation (2012) and editor of Directory of World Cinema: Turkey (2013). Her academic interests are on Middle Eastern film and television; representation of 'honour' crimes in the media, and women's cinema. She writes frequently on issues around gender and culture for the Huffington Post (UK) and for her co-authored blog on women's cinema: Auteuse Theories.

Kat Banyard is the author of The Equality Illusion: The Truth about Women and Men Today. In 2014 her book was dramatised in the play Blurred Lines, premiering at the National Theatre. Kat is also founder of UK Feminista - an organisation supporting grassroots feminist activism. In 2010 Kat was named by the Guardian as 'the most influential young feminist in the country' and in 2011 was named one of the Observer's 50 contemporary innovators, described as 'Gamechangers whose vision is transforming the world around us'. Kat was previously Campaigns Officer at the Fawcett Society and Women's Development Worker at the Northern Refugee Centre.

Oliver Brooks is a PhD student in The School of Film Television and Media Studies at the University of East Anglia. His PhD is an ethnographic study of contemporary football fans while his other research 
interests include fan studies, gender politics, rituals of representation and media power.

Victoria Cann is a lecturer in the Humanities at the University of East Anglia. Alongside her academic interests which lie broadly in the politics of identity and youth gender identities more specifically, she is passionate about raising feminist consciousness in the community having co-founded the community group Day of the Girl Norwich and helps to run Norwich Feminist Network.

Emily Harmer is currently a research associate at Loughborough University's Department of Social Sciences, where she also gained her $\mathrm{PhD}$ in 2012. Her research focuses on analysing continuities and changes in the way politics has been mediated over time and the representation of women in political news.

Sarah Ralph is a research associate in the School of Film, Television and Media Studies at the University of East Anglia, working on the 3-year (2012-2014) AHRC-funded research project, 'Make Me Laugh: Creativity in the British Television Comedy industry'. She is the coauthor (with Brett Mills) of two reports on the contemporary British television comedy industry submitted to the Department of Culture, Media and Sport. She is an editorial board member of Participations, one of the research team on the 'Remembering Alien' project, and co-editor of a forthcoming special edition of Celebrity Studies on audiences and celebrity.

Heather Savigny is Senior Lecturer in Politics at the Media School, Bournemouth University. She researches in the areas of media, politics, gender, women in higher education and heavy metal. She has published in a variety of journals, her most recent publication is the co-authored (with Deirdre O'Neill) 'Female politicians in the British press: The exception to the 'masculine' norm?' which was featured in the New Statesman as 'it's 2014 - is politics and media still a man's game?'. She is co-founder of the Women's Academic Network at Bournemouth University.

Liesbet van Zoonen is Professor of Media and Cultural Studies at Loughborough University (UK) and Erasmus University Rotterdam (NL). Her work has focused on the social relevance of popular culture, and has always had a clear gender focus. She is an editor of the 
European Journal of Communication, and is on the editorial board of most international journals in the field of media and cultural studies.

Helen Warner is Lecturer in Cultural Politics, Communications and Media Studies at the University of East Anglia. Her research focuses on the intersection between gender, fashion and celebrity culture. She has published articles on contemporary US television, fashion and celebrity culture in several journals including the Journal of Popular Narrative Media, Film Fashion and Consumption and SCAN: Journal of Media Arts Culture and Media, Culture and Society. Her monograph, Fashion on TV: Identity and Celebrity Culture was published in April 2014.

\section{Notes}

1. All examples taken from The Illusionists, a documentary in the making about beauty ideals, http://theillusionists.org/2013/04/the-problem-withdove/, last accessed April 24, 2014.

2. I wrote about this in the preface to Krijnen, Alvares and Van Bauwel (2011).

3. http://everydaysexism.com/, last accessed April 24, 2014.

4. http://femfreq.tumblr.com/post/24474432605/harassment-misogynyand-silencing-on-youtube, last accessed April 24, 2014. 